\title{
Genetic Divergence Studies in Garlic (Allium sativum L.) through Morphological Features
}

\author{
Siddhant Shekhar Mishra ${ }^{1}$, C.N. Ram ${ }^{1}$, Satish Kr. Chakravati ${ }^{2}$, Manish K. \\ Vishwakarma ${ }^{3}$, Pramod Kr. Singh ${ }^{2}$ and Vinod Bahadur Singh ${ }^{2}$ \\ ${ }^{1}$ Department of Vegetable Science, ${ }^{2}$ Krishi Vigyan Kendra, Maharajganj (N.D.U.A \& T, \\ Kumarganj, Faizabad U.P.), India \\ ${ }^{3}$ Department of Genetics and Plant Breeding, BHU, Varanasi, 221005, India
}

*Corresponding author

\begin{tabular}{|c|c|}
\hline \multicolumn{2}{|r|}{ A B S T R A C T } \\
\hline & \multirow{5}{*}{$\begin{array}{l}\text { For the assessment of the Genetic diversity among } 80 \text { germplasm of Garlic, an experiment } \\
\text { was conducted at main experimental station, Narendra Deva University of Agriculture \& } \\
\text { Technology, Faizabad (U.P.) by using } 12 \text { morphological traits. Divergence analysis } \\
\text { grouped tested genotypes in the nine distinct non-over lapping clusters. The maximum } \\
\text { inter-cluster distance was observed between cluster VII and III ( } 39.852) \text {, these two clusters } \\
\text { were genetically diverse to each other. However, the minimum inter-cluster } D^{2} \text { value was } \\
\text { recorded in case of cluster I and cluster II, as these two clusters were genetically not } \\
\text { diverse to each other. Cluster VII was most important because } 03 \text { genotypes in this cluster } \\
\text { having the most important diverse characters, because it showed maximum mean values. } \\
\text { These clusters could be useful in heterosis breeding to achieve more genetic gain. The } \\
\text { percent contribution was found highest for plant height followed by length of leaf, number } \\
\text { of cloves per bulb, and total soluble solids for total divergence among the available } \\
\text { genotypes of garlic. The current study concluded that on the basis of phenotypic } \\
\text { characters, genotypes were highly diverse, which could be exploited for future heterosis } \\
\text { breeding program and useful for selection of better recombinant. }\end{array}$} \\
\hline $\begin{array}{l}\text { Genetic divergence, } \\
\text { Allium sativum } \\
\text { Morphological } \\
\text { features }\end{array}$ & \\
\hline Article Info & \\
\hline $\begin{array}{l}\text { Accepted: } \\
\text { 10 November } 2018 \\
\text { Available Online: } \\
10 \text { December } 2018\end{array}$ & \\
\hline & \\
\hline
\end{tabular}

\section{Introduction}

Garlic (Allium sativum L.) a monocotyledonous vegetable especially used as spice and flavoring agent in cuisine (Velisek et al., 1997). Its Center of Origin is Central Asia (Kazakhstan) while China and the Mediterranean area are its secondary centers of diversification (Etoh and Simon, 2002).Garlic bulb is extraordinary medicine for enormous diseases (Mishra et al., 2018). Its consumption reduces the risk of heart disease by cutting down cholesterol level. It has good cure against some stomach disease and sore eyes and cough. Its juice has medicinal properties to cure skin diseases. Garlic contains moisture $62.8 \%$, protein $6.3 \%$, carbohydrate $29 \%$, fiber $0.80 \%$, fat $0.1 \%$, mineral matter $1.00 \%$, calcium $0.03 \%$, phosphorus $0.31 \%$, and iron $0.001 \%$ per $100 \mathrm{~g}$ 
fresh peeled garlic cloves. It also contains vitamin $A 175 \mathrm{IU}$, vitamin $\mathrm{B}_{1}, 0.68 \%$ and vitamin $\mathrm{B}_{2}, 0.08 \%$ in dehydrated garlic powder.

India is the second largest producer after China with the average productivity of 5.4 tons/ha, which is low in comparison to the other garlic growing countries (Singh et al., 2012). In India, Madhya Pradesh is the leading state in garlic production, its share, 0.06 Million hectare area with 0.27 Million tonnes production. The important garlic growing states are Andhra Pradesh, Gujarat, Maharashtra, Orissa, Rajasthan, Tamil Nadu and Uttar Pradesh. The garlic is grown on a large acreage through clonal propagation, which is main reason for narrowing genetic base, and reducing the genetic variation. Therefore, it become necessary to collect basic information on genetic diversity and other statistical parameters that could help in selection, exploitation of heterosis and obtain superior recombinants for genetic improvements to achieve the more yield of the crop.

\section{Materials and Methods}

Eighty (80) diverse genotypes of garlic (Allium sativum L.) in Augmented Block Design (Table 1) at Main Experimental Station Department of Vegetable Science, Narendra Deva University of Agriculture \& Technology, Narendra Nagar (Kumarganj), Faizabad (U.P.). Each block keeping $30 \mathrm{~cm}$ distance between the row and the distance of plant to plant was maintained at $10 \mathrm{~cm}$. The basal fertilizers were applied at the rate of 30 tonnes FYM, 125:100:65kg NPK per hectare. The recommended agronomic practices were followed to raise a good crop. Observations were recorded on five randomly selected plants for twelve yield characters i.e. plant height $(\mathrm{cm})$, number of leaves per plant, length of leaf $(\mathrm{cm})$, width of leaf $(\mathrm{cm})$, neck thickness of bulb $(\mathrm{cm})$, diameter of bulb $(\mathrm{cm})$, bulb yield per plant $(\mathrm{g})$, number of cloves per bulb, weight of clove $(\mathrm{g})$, length of clove $(\mathrm{cm})$, diameter of clove $(\mathrm{cm})$ and total soluble solids (\%). The mean data on twelve characters from the experiment were used for analysis.

\section{Results and Discussion}

The studies on genetic divergence among 80 genotypes of garlic were carried out by using Mahalanobis $\mathrm{D}^{2}$ statistics. Overall, eighty genotypes of garlic were grouped in nine distinct non-over lapping clusters (Table 1). This indicated that presence of considerable diversity in the genotypes. The major clusters in the above mentioned genetic divergence analysis contained frequently the genotypes of heterogeneous origin. Although the genotypes of same origin or geographic region were also found to be grouped together in the same cluster. The instances of grouping of genotypes of different origin or geographic region in same cluster were frequently observed. This suggested that there was no parallelism between genetic and geographic diversity. All genotypes were divided into nine clusters (Table 1). Cluster I (18) had maximum number of genotypes followed by clusters IV (13), cluster II (12), cluster VI (10), cluster VIII (8), cluster V (6), cluster IX (6), and cluster III (4). While, cluster VII (3) had lowest number of genotypes. Similar findings were reported by Khar et al., (2006).

The averages inter and intracluster distance has been mentioned in Table 2. The maximum intra-cluster $\mathrm{D}^{2}$ value observed in cluster VII (21.881) while minimum was in VI (13.508). The maximum inter-cluster distance was observed between cluster VII and III (39.852), which suggested that members of these two clusters are genetically very diverse to each other. Followed by inter-cluster distance between VI and cluster IX (39.451). 
Table.1 Clustering pattern of eighty garlic genotypes on the basis of Non-hierarchical Euclidean Cluster Analysis for 12 characters

\begin{tabular}{|c|c|c|}
\hline $\begin{array}{l}\text { Cluster } \\
\text { Number }\end{array}$ & $\begin{array}{l}\text { Number of } \\
\text { genotypes }\end{array}$ & Genotypes \\
\hline $\mathrm{I}$ & 18 & $\begin{array}{l}\text { NDG-2,NDG-22,NDG-21,NDG-71,NDG-10,G-41,NDG-8,NDG-1, NDG-3,NDG- } \\
\text { 4,G-282,G-50,NDG-70,NDG-73,NDG-12,NDG-15,NDG-23,NDG-55 }\end{array}$ \\
\hline II & 12 & $\begin{array}{l}\text { NDG-7,NDG-16,NDG-11,NDG-72,NDG-14,NDG-18, NDG-46,NDG-41,NDG- } \\
\text { 40,NDG-58,NDG-57,NDG-61 }\end{array}$ \\
\hline III & 4 & NDG-13,NDG-67,NDG-68,NDG-69 \\
\hline IV & 13 & $\begin{array}{l}\text { NDG-17,NDG-20,NDG-19,NDG-45,NDG-63,NDG-24,NDG-47,NDG-49,NDG- } \\
\text { 25,NDG-48,NDG-56,NDG-64,NDG-65 }\end{array}$ \\
\hline $\mathrm{V}$ & 6 & NDG-5,NDG-6,NDG-9,NDG-75,NDG-77,NDG-77 \\
\hline VI & 10 & $\begin{array}{l}\text { NDG-26,NDG-32,NDG-43,NDG-42,NDG-50,NDG-62,NDG-74,NDG-51,NDG- } \\
\text { 52,NDG-53 }\end{array}$ \\
\hline VII & 3 & NDG-29,NDG-30,NDG-27 \\
\hline VIII & 8 & NDG-31,NDG-44,NDG-54,NDG-36,NDG-66,NDG-59,NDG-60,NDG-28 \\
\hline IX & 6 & NDG-33,NDG-38,NDG-39,NDG-34,NDG-35,NDG-37 \\
\hline
\end{tabular}


Int.J.Curr.Microbiol.App.Sci (2018) 7(12): 1013-1020

Table.2 Estimates of average intra and inter-cluster distances for 9 clusters in garlic

\begin{tabular}{|c|c|c|c|c|c|c|c|c|c|}
\hline Clusters & I & II & III & IV & V & VI & VII & VIII & IX \\
\hline I & 14.428 & 18.386 & 23.204 & 20.519 & 22.817 & 22.775 & 36.222 & 26.513 & 31.702 \\
\hline II & & 14.395 & 23.531 & 20.694 & 21.535 & 21.762 & 31.946 & 23.983 & 31.881 \\
\hline III & & & 14.033 & 25.117 & 30.494 & 33.757 & 39.852 & 34.122 & 38.154 \\
\hline IV & & & & 14.754 & 30.458 & 24.017 & 36.969 & 24.380 & 39.451 \\
\hline V & & & & & 13.657 & 22.050 & 32.154 & 27.508 & 26.312 \\
\hline VI & & & & & & 13.508 & 35.455 & 20.409 & 29.675 \\
\hline VII & & & & & & & 21.881 & 26.194 & 32.304 \\
\hline VIII & & & & & & & & 14.346 & 23.480 \\
\hline IX & & & & & & & & & 18.995 \\
\hline
\end{tabular}




\section{Int.J.Curr.Microbiol.App.Sci (2018) 7(12): 1013-1020}

Table.3 Cluster means for 12 characters in Garlic

\begin{tabular}{|c|c|c|c|c|c|c|c|c|c|c|c|c|}
\hline $\begin{array}{c}\text { Cluster/ } \\
\text { Characters }\end{array}$ & $\begin{array}{l}\text { Plant } \\
\text { height } \\
(\mathrm{cm})\end{array}$ & $\begin{array}{c}\text { Number } \\
\text { of } \\
\text { leaves } \\
\text { per } \\
\text { plant }\end{array}$ & $\begin{array}{l}\text { Length } \\
\text { of leaf } \\
\text { (cm) }\end{array}$ & $\begin{array}{l}\text { Width } \\
\text { of } \\
\text { leaf } \\
(\mathrm{cm})\end{array}$ & $\begin{array}{l}\text { Diameter } \\
\text { of Bulb } \\
(\mathrm{cm})\end{array}$ & $\begin{array}{l}\text { Neck } \\
\text { Thickness } \\
\text { of Bulb } \\
\text { (cm) }\end{array}$ & $\begin{array}{l}\text { Bulb } \\
\text { Yield } \\
\text { per } \\
\text { plant } \\
(\mathrm{g})\end{array}$ & $\begin{array}{c}\text { Number } \\
\text { of } \\
\text { cloves } \\
\text { per } \\
\text { Bulb }\end{array}$ & $\begin{array}{l}\text { Length } \\
\text { of } \\
\text { Clove } \\
(\mathrm{cm})\end{array}$ & $\begin{array}{l}\text { Weight } \\
\text { of } \\
\text { Clove } \\
\text { (g) }\end{array}$ & $\begin{array}{c}\text { Diameter } \\
\text { of Clove } \\
(\mathrm{cm})\end{array}$ & $\begin{array}{c}\text { T.S.S. } \\
(\%)\end{array}$ \\
\hline I & 64.522 & 7.959 & 35.954 & 1.982 & 4.044 & 1.4462 & 24.467 & 22.785 & 2.366 & 1.568 & 1.503 & 33.812 \\
\hline II & 61.844 & 8.274 & 33.108 & 1.695 & 4.029 & 1.397 & 23.560 & 21.151 & 2.378 & 1.328 & 1.498 & 32.356 \\
\hline III & 62.842 & 8.418 & 35.540 & 1.885 & 3.793 & 1.635 & 22.749 & 20.230 & 2.417 & 1.212 & 1.432 & 38.174 \\
\hline IV & 42.533 & 6.762 & 28.148 & 1.641 & 3.244 & 1.529 & 19.741 & 17.197 & 2.302 & 1.320 & 1.515 & 34.644 \\
\hline V & 51.592 & 7.956 & 29.327 & 1.659 & 3.652 & 1.443 & 22.525 & 19.992 & 2.201 & 1.203 & 1.438 & 35.234 \\
\hline VI & 68.222 & 8.200 & 36.789 & 2.001 & 4.048 & 1.605 & 22.670 & 22.233 & 2.465 & 1.236 & 1.292 & 37.180 \\
\hline VII & 69.974 & 8.663 & 39.927 & 1.173 & 4.529 & 1.219 & 26.824 & 27.228 & 2.579 & 1.247 & 1.413 & 36.305 \\
\hline VIII & 59.867 & 7.743 & 31.852 & 1.779 & 3.661 & 1.583 & 22.423 & 20.844 & 2.260 & 1.151 & 1.221 & 36.766 \\
\hline IX & 52.523 & 7.639 & 30.610 & 1.228 & 3.574 & 1.366 & 25.400 & 23.534 & 2.331 & 1.415 & 1.508 & 32.997 \\
\hline
\end{tabular}




\section{Contribution \% towards Divergence}

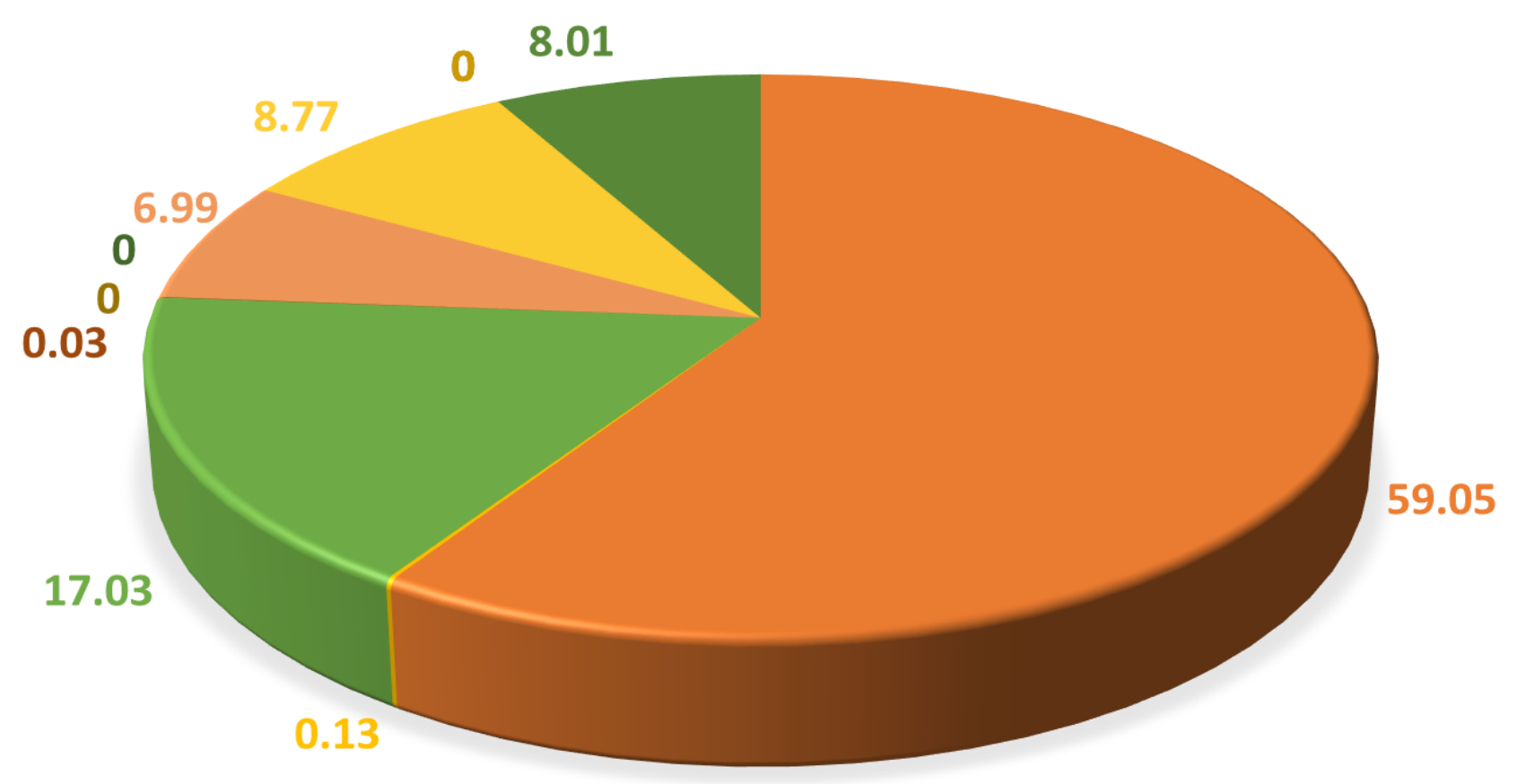

ㄱant height $(\mathrm{cm})$

Width of leaf $(\mathrm{cm})$

Bulb Yield per plant (g)

回 Weight of Clove (g)
Number of leaves per plant

Diameter of Bulb (cm)

Number of cloves per Bulb

国 Diameter of Clove $(\mathrm{cm})$
国 Length of leaf (cm)

回 Neck Thickness of Bulb (cm)

Length of Clove (cm)

回T.S.S. (\%) 
Inter cluster distance between 15 clusters were obtained $>30$. The minimum intercluster $\mathrm{D}^{2}$ value was recorded in case of cluster I and cluster II (18.386) followed by cluster VI and cluster VII (20.409). The higher inter-cluster distance indicated greater genetic divergence between the genotypes of these clusters, while, lower inter cluster values between the clusters suggested that the genotypes of the clusters were not much genetically diverse from each other. This was supported by Khar et al., (2006) and Kumar et al., (2011)in same and other crop, respectively.Saxesenaet al., (2013)also stated that genotypes belonging to the cluster with maximum inter cluster distance are genetically more divergent. Therefore, favorable broad spectrum genetic variability for bulb yield improvement may be achieve by adopting the selection of genotypes based on large cluster distances from all the clusters. Hybrids between genotypes belonging to the same cluster never be expected to have desirable segregants, because they are less divergent. Consequently, hybridization between genetically diverse parents from different distant cluster always bring together diverse nature of genes in one pool or genotype. Complementary interaction of divergent genes in parents always yieldpromising hybrids.

Cluster VII showed maximum mean values 69.974 for the plant height, number of leaves per plant (8.663), length of leaf (39.927), diameter of bulb (4.529), bulb yield per plant (26.824), number of clove per bulb (27.228) and length of clove (2.579) (Table 3). Cluster VI showed highest mean for width of leaf (2.001). Cluster III showed highest mean for neck thickness of bulb (1.635), and total soluble solids (38.174). Cluster I showed highest mean for weight of clove (1.568). Cluster IV showed highest mean for diameter of clove (1.515). Singh et al., (2012) also reported similar results. Cluster VII was most important because three genotypes in this cluster having the most important diverse characters, which might be used for the several traits. Albeit, as these clusters are comparatively more diverse, these clusters could be exploited for the breeding to achieve more genetic gain. The present findings were in accordance with the findings of (Kaushik $e t$ $a l$., 2016). The maximum $\mathrm{D}^{2}$ values of any character may be greater decisive factor to choose the cluster toaim of further selection.

A perusal of percent contribution showed that plant height was found for highest 59.05 contribution followed by length of leaf (17.03), number of cloves per bulb (8.77) and total soluble solids (8.01) for total divergence among the available genotypes of garlic (Figure 1). While number of leaves per plant, bulb yield per plant, diameter of bulb, contributed very low towards the divergence. Similar results were reported by Kaushik et al., (2016) and Shashidhar and Dharmatti (2005).

\section{Acknowledgment}

The work on garlic reported in this paper has been supported by research and teaching faculties of the Department of Vegetable Science, N.D.U.A.T., Kumarganj, Faizabad.

\section{References}

Etoh, T. and P. W. Simon (2002). Diversity, fertility and seed production of garlic. Allium crop science: Recent advances. In: Rabinovitch, H. D. and L. Currah (eds.) CABI Publishing, Wallingford, UK, 101-117.

Kaushik S, Kumar M, SPrakash,VKumar, MK Singh, B. Singh, S Malik and K Singh (2016). Study of genetic diversity in garlic (Allium sativum L.) by using morphological characters. Prog. Agric. 16 (2): 204-210. 
Khar, A., Devi, A. A., Mahajan, V., Lawande, K. E. (2006). Genetic divergence analysis in elite lines of garlic (Allium sativum L.). J. Maharashtra Agric. Univ., 31(1):52- 55.

Kumar, H., Anubha, M. K. Vishwakarma and J. P. Lal (2011). Morphological and molecular characterization of Brassica rapassp yellow sarson mutants. Journal of Oilseed Brassica, 2(1): 1-6.

Mishra SS, CN Ram, SKChakravati, MK Vishwakarma, R Arya and BPal (2018). Assessment of genetic variability and correlation studies in garlic (Allium sativum L.). Journal of Pharmacognosy and Phytochemistry; SP1: 3150-3153.

Saxesena RR, Lal GM, PS Yadav and MK Vishwakarma (2013) Diversity analysis and identification of promising lines for hybridization in field pea (Pisum sativum L.), The Bioscan, 8(4): 13371340.

Shashidhar, T. R., and Dharmatti, P. R. (2005). Genetic divergence studies in garlic. Karnataka Journal of Horticulture, 1(3): 12- 15.

Singh G, C.N. Ram, A Singh, SP Shrivastav, PK Maurya, P Kumar and Sriom (2018) Genetic Variability, Heritability and Genetic Advance for Yield and its Contributing Traits in Garlic (Allium sativum L.). Int. J. Curr. Microbiol. App. Sci, 7(2): 1362-1372.

Velisek, J., R. Kubec and J. Davidek (1997). Chemical composition and classification of culinary and pharmaceutical garlic-based products. Lebensem Unters Forsch., 204: 161164.

\section{How to cite this article:}

Siddhant Shekhar Mishra, C.N. Ram, Satish Kr. Chakravati, Manish K. Vishwakarma, Pramod Kr. Singh and Vinod Bahadur Singh. 2018. Genetic Divergence Studies in Garlic (Allium sativum L.) through Morphological Features. Int.J.Curr.Microbiol.App.Sci. 7(12): 1013-1020. doi: https://doi.org/10.20546/ijcmas.2018.712.126 